\title{
Drainage Pattern at Kaligesing Area, Purworejo District, Central Java
}

\author{
T. Listyani R.A. ${ }^{1, *}$ and $E v$. Budiadi ${ }^{1}$ \\ ${ }^{1}$ Geological Engineering Department, Institut Teknologi Nasional Yogyakarta, Babarsari, \\ Caturtunggal, Depok, Sleman, Yogyakarta 55281, Indonesia
}

\begin{abstract}
The Kaligesing area is part of the western part of the West Progo Dome. As the hard water area, water resources should be important problem to support rural development. The characteristics of the drainage as an indicator of water resources potential need to be understood in order to assess water potential. This paper wants to describe drainage characteristics as one of potential water resources indicators. The sufficient water resource is important for rural development. Result of the research shows that geological conditions allow this area to have relatively little water potential, but surface water can develop through rock-controlled flow patterns and geological structures. The flow characteristics in the area show rectangular, sub dendritic, and trellis patterns. Rivers develop genetically with consequent and subsequent types. Based on the quantity of water, the rivers in the study area include the intermittent and ephemeral rivers. Meanwhile, based on tectonics these rivers can be classified as superimposed rivers, where geological structures facilitate the formation of rivers in the research area. The river order in the study area shows the order of $1-4$. Meanwhile, the density of the river is $0.81-1.86 \mathrm{~km} / \mathrm{km}^{2}$ with young to mature river stages.
\end{abstract}

\section{Introduction}

This research was conducted in part of West Progo Hills, known as a hard water area. Nowadays, the research area is a fairly developed area. Community life and land use, including agriculture and plantations, require water resources. Water needs to support rural development. Therefore, the study of surface water is an important part of the research area.

This study is intended as a descriptive geomorphological survey. Goal of the research is knowing the characteristics of the drainage as an indicator of water resources potential. By knowing the drainage characteristics, it is expected that the potential of water resources can be easily assessed. The drainage patterns characteristics, both of the form and textures of channels and tributaries depend on local topography and subsurface geology $[1,2]$. Thus, by studying geology we can understand the potential of water resources which are very much needed in the life of rural communities.

\footnotetext{
*Corresponding author: lis@itny.ac.id
} 
Result of the research is a description of the geomorphic variables of the river network, especially in terms of drainage systems. These characteristics include drainage pattern, river classification, order of branching, density \& stadia of river. They reflect the potential of water resources. A dense flow pattern with many branches can indicate the better potential for water to be stored in the channel. A considerable quantity of water is needed by rural development and supports local agriculture.

The West Progo Hills is known as an area that has a landscape with quite steep reliefs to very steep, strong dissected with relatively hard and compact rocks. The geological structure is quite intensively developed in this area. The landscapes and drainage seems under varying conditions, both high and low. Various drainage conditions need to be studied to see the potential of water is also a special concern in this study considering that many areas in West Progo are included in difficult water areas.

Geomorphological aspects will be very important for the community so that they can understand the water conditions in the local area. Both surface water and shallow groundwater usually controlled by geological aspects, especially on topography and geological structures $[3,4]$. The quality of water in West Progo Dome is usually fairly good for daily life [5]. Beside its quality, knowing surface and subsurface water quantity is also important for the community in the area, in order to fulfill water needs independently.

The water quantity can be known from drainage approach. The drainage aspect is an important part in understanding the geological conditions of an area. Information about the characteristics of drainage will help interpret the geological conditions of an area, and is useful for identifying potential water resources in the local area. The characteristics of drainage studied include flow patterns, river orders, river genetics and river classifications.

\section{Methods}

The research has been done at Kaligesing area, Purworejo District, Central Java Province (Figure 1). According to its physiography (Van Bemmelen, 1949, in [4]), the study area was included in the western part of West Progo Dome. The steep - very steep morphology is found in this area. It may classified as gently undulating to steeply dissected mountainous landform [6]. The studied area is generally occupying morphology with moderate to coarse relief in almost all parts of the study area.

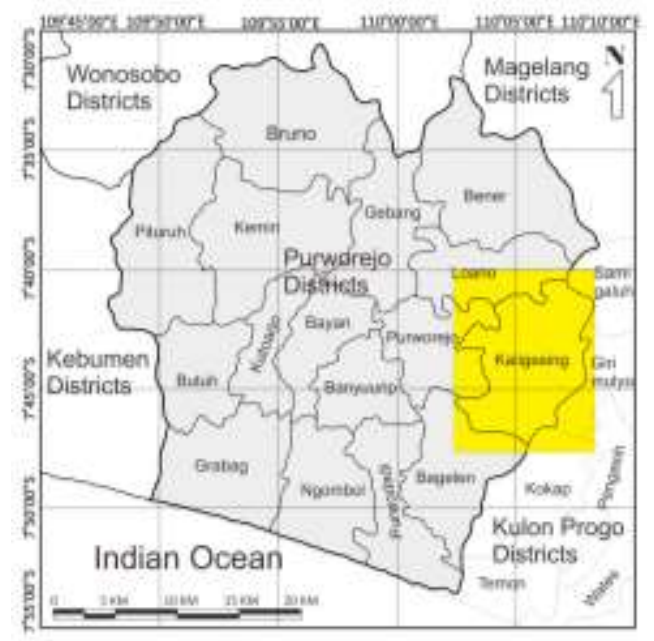

Fig. 1. Research area. 
Research on the characteristics of drainage in Kaligesing begins with geomorphological mapping in the field with a focus on attention to the fluvial landscape. Data collection of river characteristics is carried out directly in the field and aided by studio analysis in the form of flow pattern analysis, river order and river density. Field work was carried out with the help of geological field tools (GPS, hammer, compass) to retrieve data on river conditions, genetic streams and river stadia. The qualitative description is carried out on the drainage aspects in the field, by observing rocks, geological structures and morphology around the river flow. Ten observation locations were chosen randomly, representing several river characters studied (Figure 2).

Determination of flow patterns and river classification refers to van Zuidam (1983 in [7, $8,9]$. Order division refers to the classification of Strahler (1952, in [7]). This classification with the Strahler system is considered to provide more simple and accurate results [7].

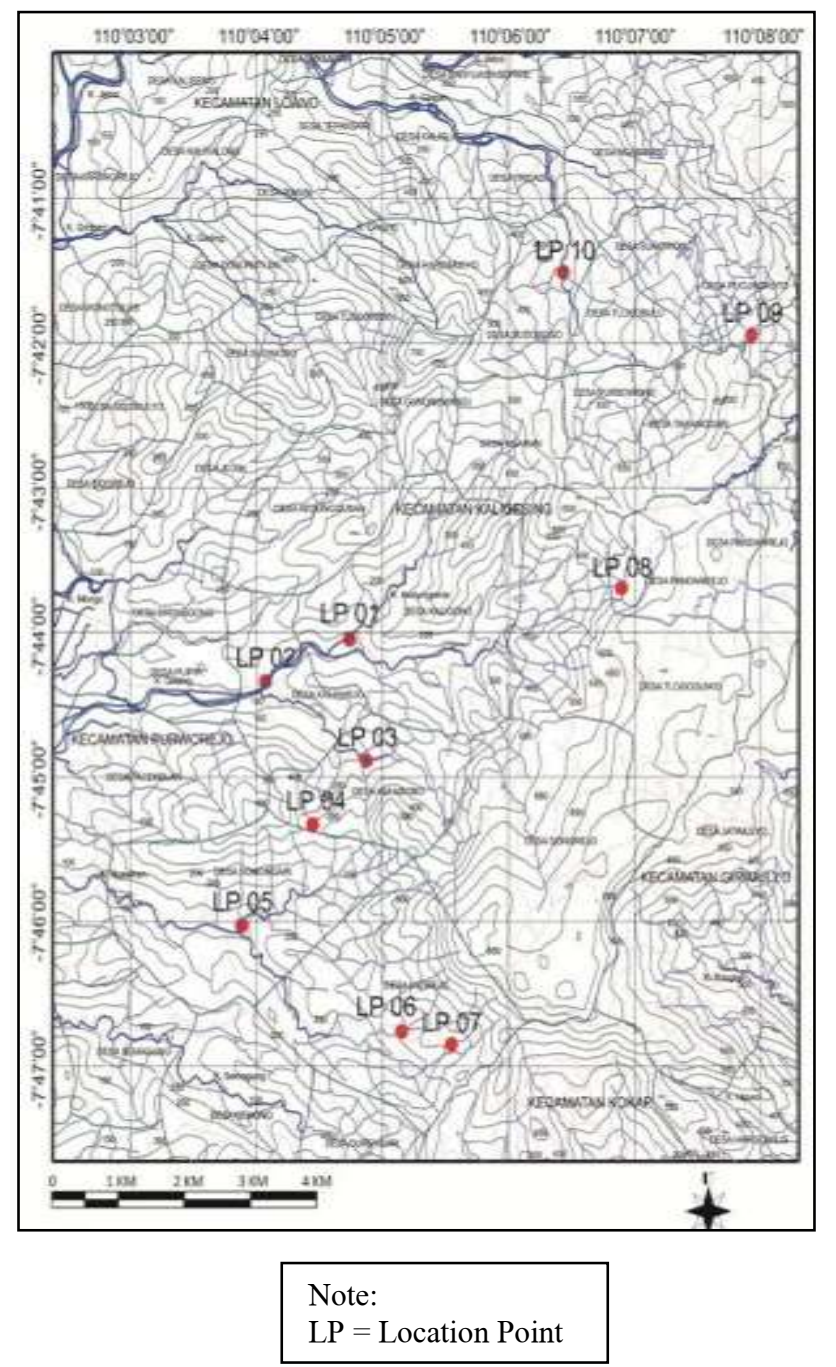

Fig. 2. Stop site of research. 


\section{Results and Discussion}

\subsection{Geologic Setting}

The morphology of the study area is mostly a rough bereft area, forming hills that are quite steep to very steep, especially in the middle to the west of the study area. Areas in the eastern part are relatively gently sloping, with undulating to rolling morphology $[6,10]$. Landscapes in the study area can be divided into three geomorphological units, namely karts hills, conical karst and structural hill units. The geology of the study area is mostly composed of Tertiary rocks which are part of the West Progo Hills stratigraphy. In general, the rocks revealed in the study area are the Old Andesite Formation (OAF) and Jonggrangan Formation (Van Bemmelen, 1949 in [4]).

Meanwhile, the geological structure in the study area is strongly influenced by the processes that occur in the Oligocene-Miocene Period. The existing structure is in the form of joints and faults. The joint structures in the study area consisted of two types, namely shear and tension joints. While the fault found in the study area is a normal fault which is relatively northwest - southeast. These structures work quite effectively. The result is an effective dissolution that occurs in weak zones formed by the presence of these structures [4].

Hydrological conditions in the Kaligesing area vary greatly according to geomorphology and geology. This area is part of the West Progo Hills system which generally has low groundwater potential. The steep slope causes the rainwater that is received by the soil surface to quickly collect in the river ways and flow to the downstream area. In this condition, rain water does not have the chance to infiltrate into the soil in sufficient quantities.

\subsection{Drainage Characteristics}

\subsubsection{Drainage Pattern}

The drainage pattern is formed of stream erodes the channels and determine its river network $[11,12]$. This pattern is built by main channel and its tributaries. The drainage patterns in the study area can be divided into three types, namely the sub dendritic, rectangular, and trellis patterns [13] (Figure 3). The sub dendritic pattern occupies the central part of the study area around Gesing river. The sub dendritic pattern has shown the influence of geological structures, reflected by several tributary patterns which are sometimes angled due to the effects of joints. The rectangular pattern is in the north, northwest, west and south of the research area made by the Bogowonto tributaries. This rectangular pattern is characterized by branches of tributaries that flow relatively perpendicular to the main river but not as closely as the trellis patterns. Meanwhile, the trellis pattern is indicated by rivers in the north eastern end of the study area. This pattern was formed by the children of Jebol river who eventually led to their main stream of Bogowonto. This pattern is characterized by branches of small rivers whose flow direction is perpendicular to the main river and relatively tight.

\subsubsection{River Classification}

Rivers can be classified according to various ways. The classifications that are often used in geomorphology are based on genetics, water quantity and tectonic setting. 


\subsubsection{Based on Genetic}

Referring to Strahler (1945, in [14]), the rivers in the study area can be divided into two genetically classified classes, namely consequent and subsequent rivers. The consequent river is the main river that flows in the direction of the slope of the rock. In this case, the main river is the main river in each sub-watershed. Thus, the rivers that form the consequent types include Gintung, Mongo, Gesing, Ngasinan, Semagung and Pringtali rivers. Most of these rivers flow on andesite breccia of the Old Andesite Formation and only a few rivers in the southeast of the study area flow past the Jonggrangan Formation limestone. Meanwhile, the subsequent river is a branch of the consequent river, usually the direction of the flow is parallel to the strike of rock layers. This subsequent river is formed by tributaries from Jebol, Mongo, Ngasinan, Semagung and Pringtali rivers (Figure 4).

The river in study area may develop to be other genetic type, depends on tectonics and exogenic processes. All of them should control water resource in West Progo Hills, especially to shallow groundwater, and may be predicted from morphology [15].

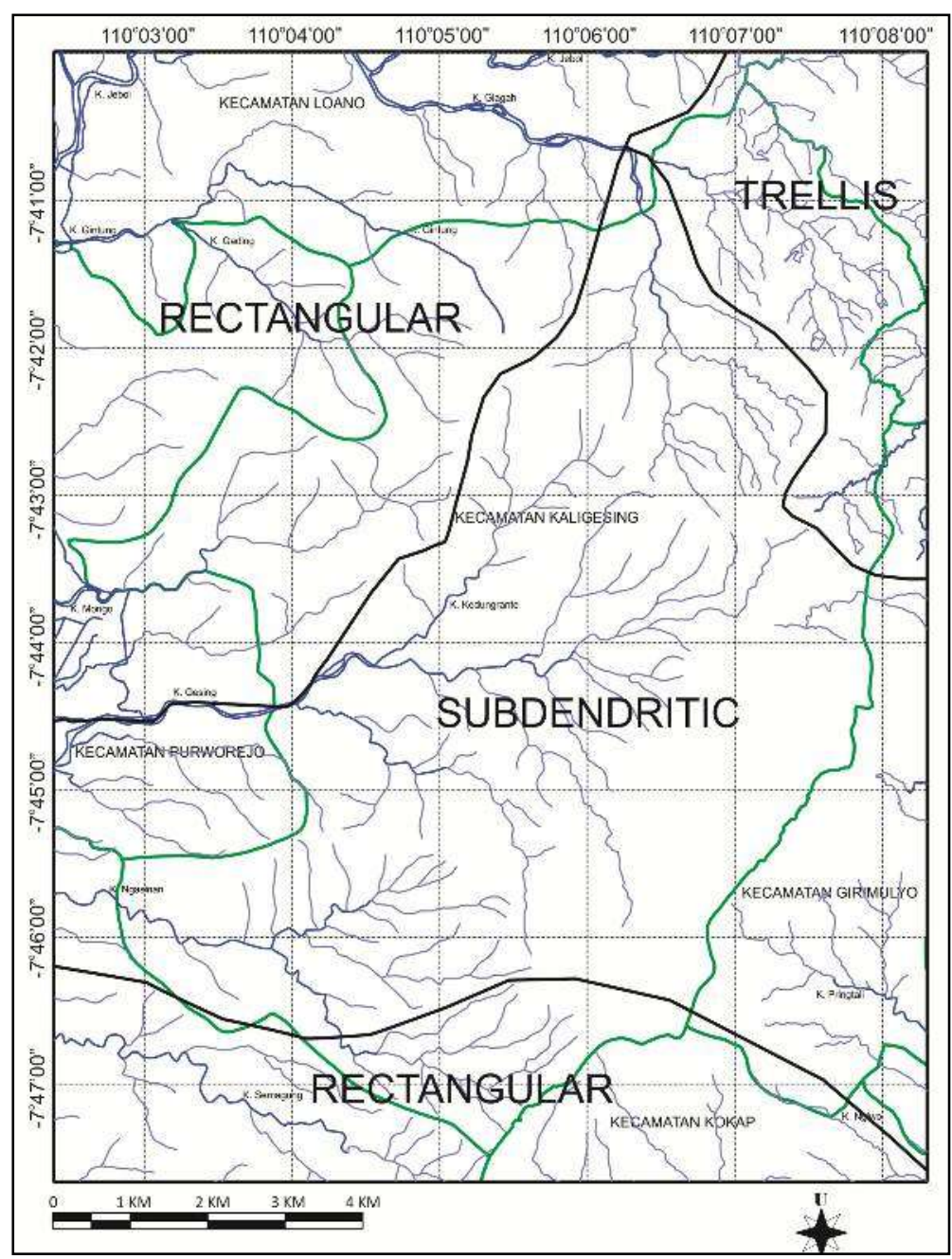

Fig. 3. Drainage pattern of research area. 


\subsubsection{Based on Water Quantity}

Based on the quantity of water or the amount of water relative to each year, rivers in the study area can be classified into intermittent and ephemeral rivers (Figure 4). Perennial river (flowing throughout the year) is not found in the study area. The intermittent river flows seasonally (seasonal flows). Perennial river can be distinguished from intermittent or ephemeral rivers by seeing dense vegetation (forest) or the presence of water in the dry season [7].

Among the intermittent rivers include Jebol, Gintung, Mongo, Gesing (Figure 4), Ngasinan, Semagung and Pringtali rivers along with some of their tributaries. The tributaries which are the upstream part of the intermittent rivers generally develop as ephemeral rivers (Figure 5).

\subsubsection{Based on Tectonic}

Geomorphic index and drainage pattern can indicate the presence of active tectonics, for example, river profile can be related to fault system in an area [16]. Active tectonics such as fold growth can be indentified by morphometry of drainage patterns or basins [17].

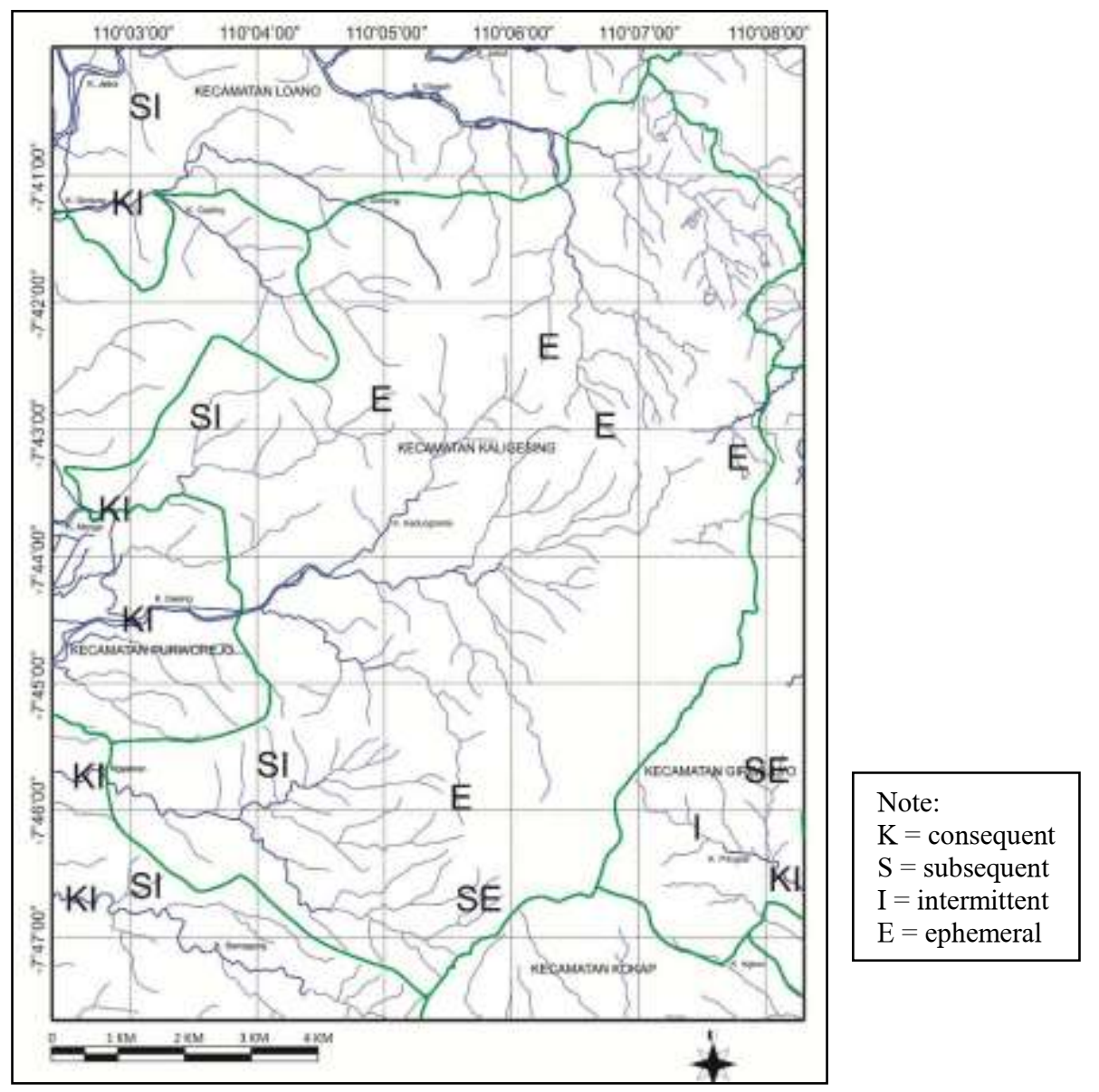

Fig. 4. Drainage patterns of research area. 

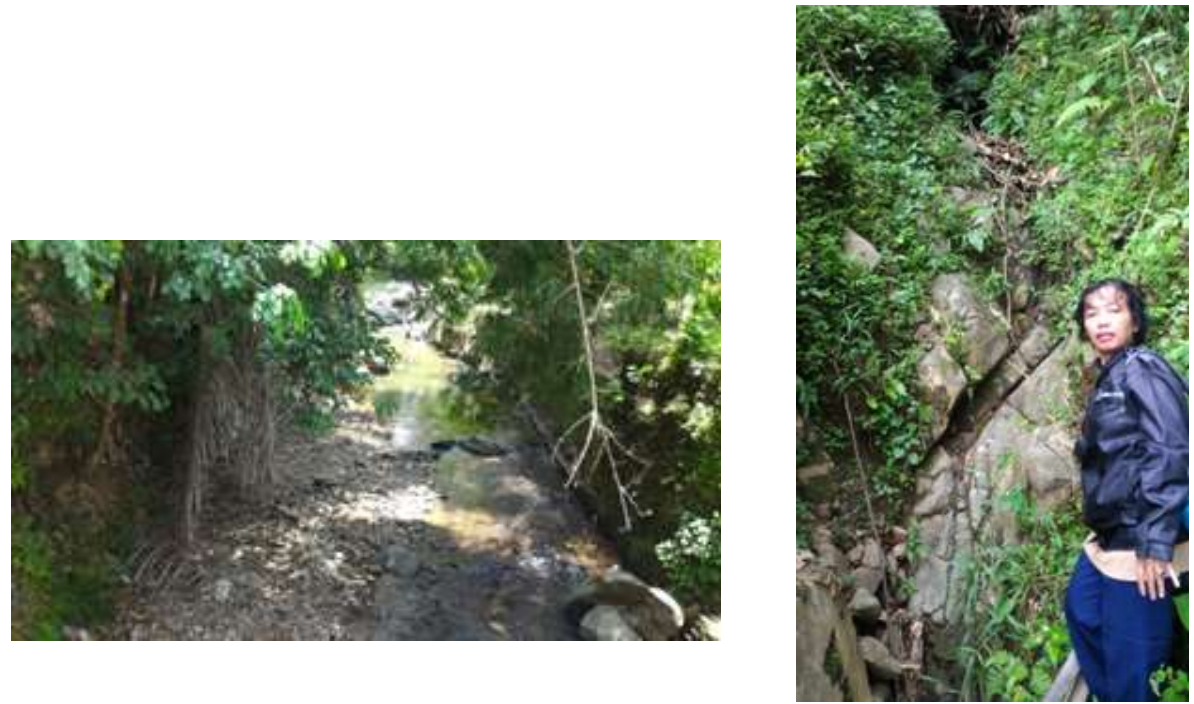

Fig. 5. Intermittent (left) and ephemeral (right) streams at Kaligesing.

Meanwhile, based on tectonic processes or geological structures, rivers in the study area include superimposed / epigenetic rivers, namely rivers formed after the surrounding rock structure [7]. This river has a younger growth than the valley. This river is formed in a certain structural field or controlled by geological structures. This river in its development carried out vertical erosion so that it cut the lower part of the rock structure, therefore the bed rock as the river bed sometimes revealed around the river channel.

\subsubsection{Order of Branching}

The rivers in the study area are the upstream part of the Bogowonto, Serang and Progo watersheds. Therefore, in this area small river flows develop in the initial order of a river (order 1). The Order 1 river is developing in almost all places in the area under study. The first order river develops well in the northeast, for example tributaries in the upper Glagah and Jebol rivers. The first order river is also formed in the middle of the study area, for example the tributaries of the Mongo, Gintung, Gesing and Ngasinan rivers (Figure 6).

The second order river is a continuation of the river that is under the order of the $1 \mathrm{st}$ order river with order 1 or 2 . The river is widely developed in various regions, in the research area, as well as the order river 3 . The $4^{\text {th }}$ order river is only in the north (Glagah river ) and the west (Gesing and Ngasinan rivers).

\subsubsection{Density and Stadia of River}

The drainage pattern is formed by a number of gullies that develop into rivers and their branches form a pattern in an area of watershed or sub-watershed area. Through topographic maps it can be observed that there are several patterns of flow that developed in the study area. Naming the watershed is based on the name of the main river. The study area was divided into 11 sub-watersheds (Table 1; Figure 7), but only one sub-watershed (Gesing Sub-watershed) was included in the whole area, while the other areas were out of the study area. 


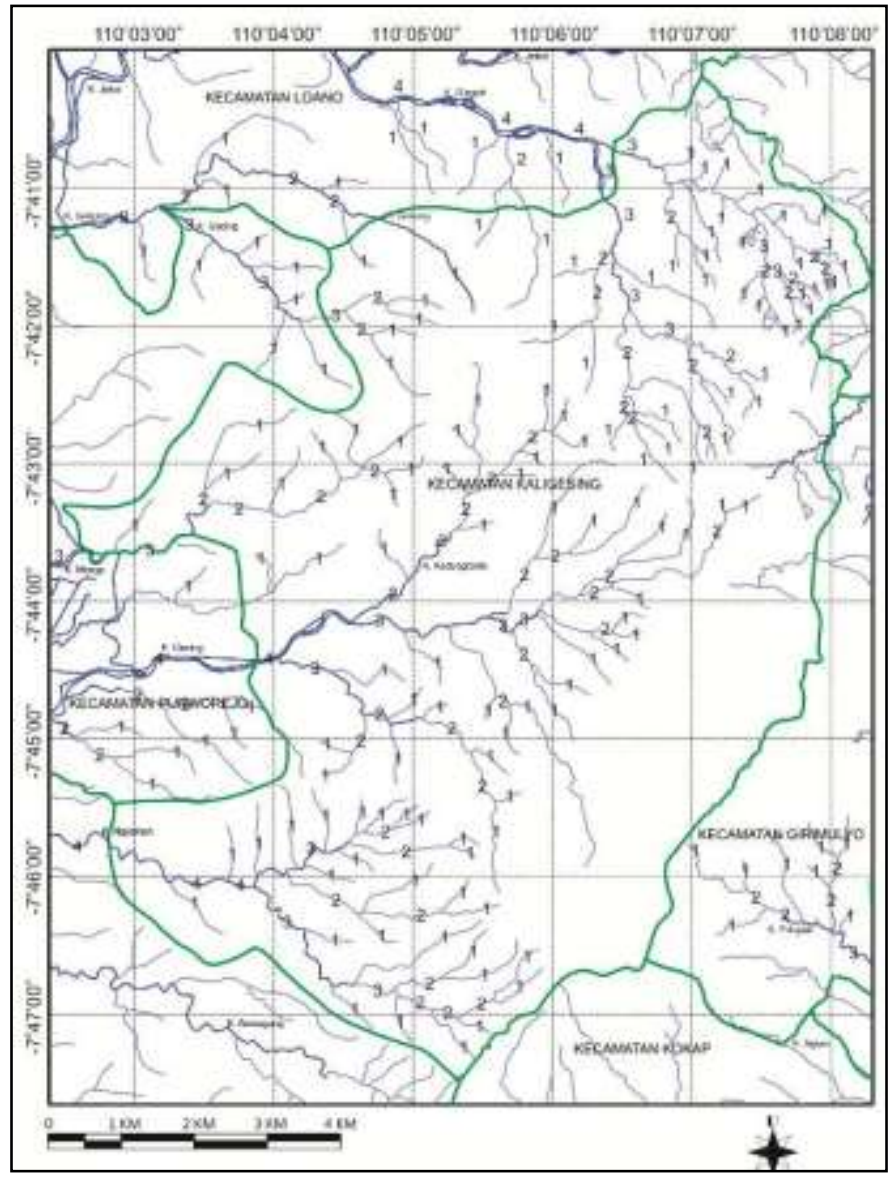

Fig. 6. Channel ordering map of research area.

Table 1. Sub-watershed with $\mathrm{Rb}$ and Dd value [10].

\begin{tabular}{|c|c|c|c|}
\hline No. & Sub watershed & Dd & Rb \\
\hline 1 & Jebol & 1.86 & 4 \\
\hline 2 & Glagah & 0.81 & 4 \\
\hline 3 & Gintung & 1.28 & 6 \\
\hline 4 & Kedungsari & 1.83 & 6 \\
\hline 5 & Mongo & 1.21 & 3.6 \\
\hline 6 & Gesing & 1.66 & 8.6 \\
\hline 7 & Ngasinan & 1.83 & 6.87 \\
\hline 8 & Semagung & 1.42 & 3.33 \\
\hline 9 & Ngiwo & 1.82 & 4.33 \\
\hline 10 & Pringtali & 1.2 & 6.6 \\
\hline 11 & Petung & 1.06 & 2.76 \\
\hline
\end{tabular}


The drainage pattern is controlled by petrophysic of rocks. Therefore, the drainage patterns also reflect the hydraulic conductivity of subsurface area [18].

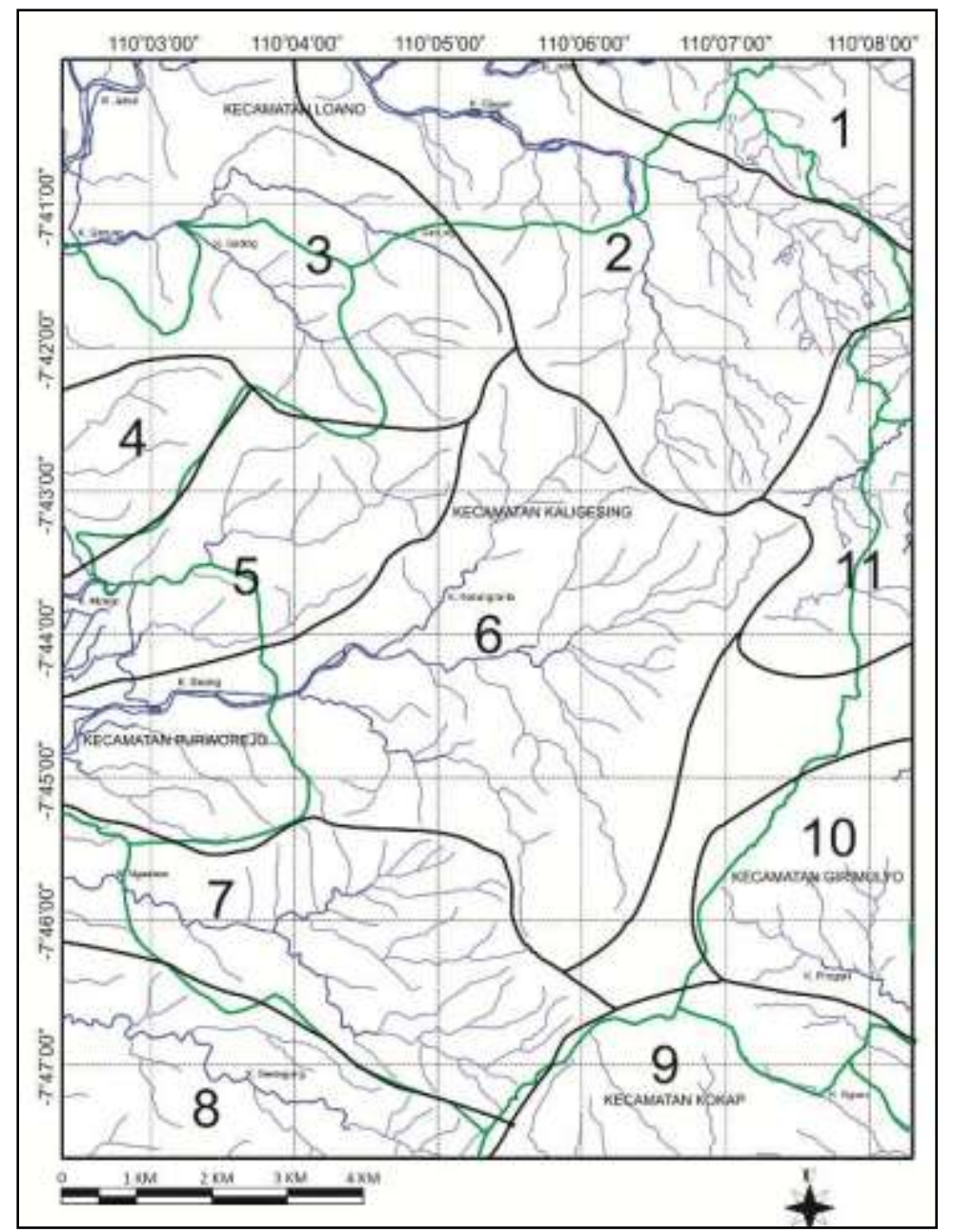

Fig. 7. Sub drainage streams at research area.

Each sub-watershed has a river branching ratio $(\mathrm{Rb})$. In this study quantitative calculations are not carried out, so the $\mathrm{Rb}$ value only refers to secondary data. The value of $\mathrm{Rb}$ is $2.76-8.6$ and Dd sub-watershed is $0.81-1.86 \mathrm{~km} / \mathrm{km}^{2}$.

The water potential is supported by hydrologic conditions of watersheds and their vicinity areas. The relatively high river density allows sufficient surface water to be accommodated in a channel and reduces fast run off. The impervious surface causes a hydrological response that is faster and larger than naturally permeable areas, even for low rainfall intensity (Dayaratne and Perera, 2008 in [19]). Even, the increased runoff can create a significant flood risk with even moderate rainfall (Westra et al, 2013 in [19]). Therefore, a river density that is high enough will support sufficient water storage, if there are permeable rocks around it, water infiltration will be possible to the underground.

Stadia river is identical to the erosion stage that it does. Rivers in the study area are generally in the young to mature stages with the following explanation. 


\subsubsection{Young Stadia}

The river in the study area is dominated by young streams, with several features as follows.

- $\quad$ Large river gradient gradients and several gullies show quite heavy flow.

- Vertical erosion is more effective, characterized by the presence of narrow river grooves with steep cliffs even almost erect.

- $\quad$ Sedimentation has not occurred.

- $\quad$ Several rapids were found (Figure 8), although the rapids were sometimes only small.

- $\quad$ The flood plain is narrow or not existent.

- V-shaped valley section

- $\quad$ The river is relatively straight.

- $\quad$ Little creeks / small river density.
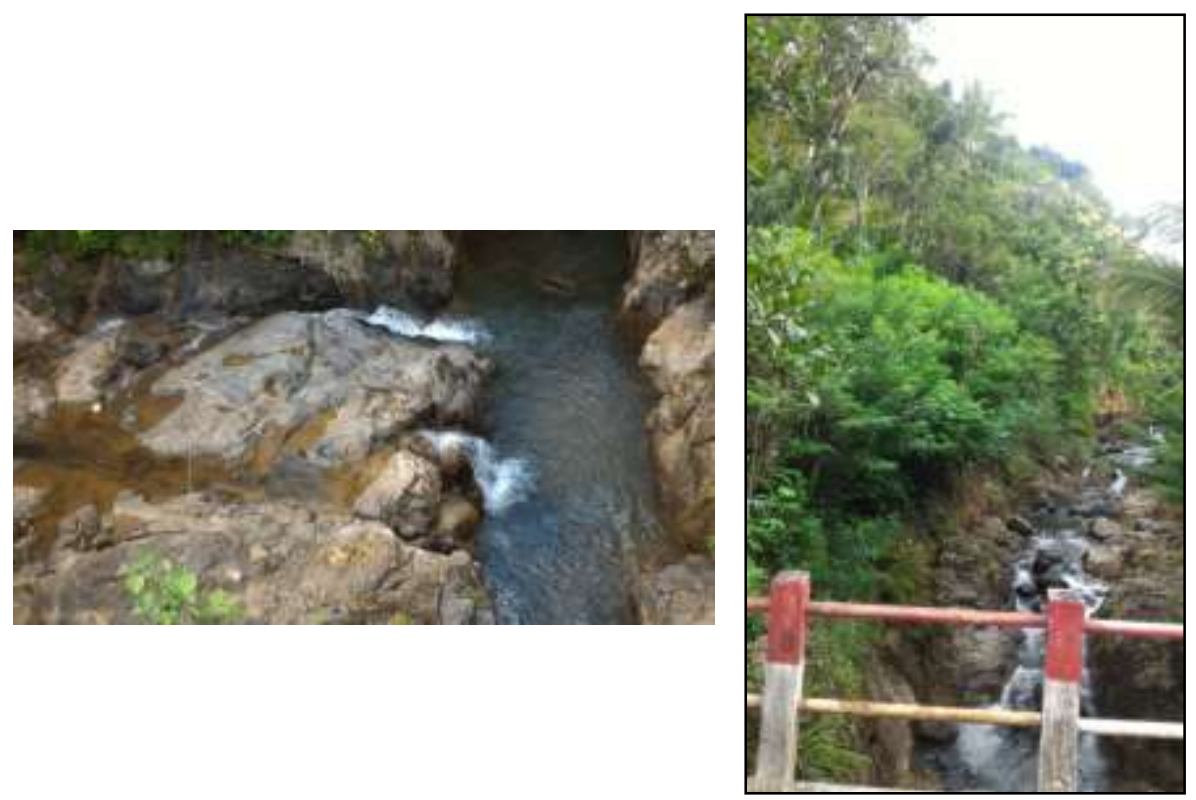

Fig. 8. The appearance of small rapids on the intersection of the Glagah river (left) and the relatively straight river morphology (Loc. 10).

\subsubsection{Mature Stadia}

Only a few rivers are found in the research area which shows the characteristics of the river in the adult stage.

- $\quad$ Smaller gradient.

- $\quad$ Lateral erosion is more effective.

- Deposition is relatively small. Sedimentation of the river begins to occur, but is relatively small compared to the old river stadia. The deposition in the body of the river can be observed in the Kedungrante river at Kaligono area (Loc. 1; Figure 9).

- $\quad$ The flood plain began to expand.

- The cross section of the valley is U-shaped. This type of valley can occur as a result of a pause after a period of strong vertical erosion or because the river follows a muscular boundary (fracture gap) or meets hard rock, thereby reducing the rate of vertical erosion [20].

- $\quad$ More tributaries. 

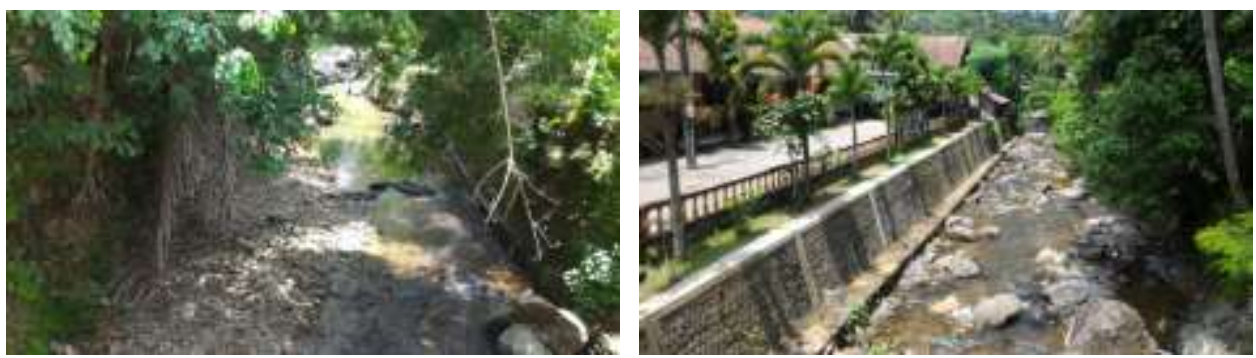

Fig. 9. Deposition on river bed at Loc.1.

\section{Conclusion}

The geology of the study area is composed of Tertiary rocks from the West Progo Hills. These rocks affect the potential of surface water in the study area, which is reflected in the characteristics of drainage. Flow characteristics in the study area showed rectangular, sub dendritic, trellis drainage patterns. Genetically, the river in the study area shows the consequent and subsequent types. Based on the quantity of water, the rivers in the study area include intermittent and ephemeral rivers. Meanwhile, based on tectonics, the rivers in the study area are superimposed rivers, where the geological structure facilitates the formation of these rivers. The rivers in the study area have a sequence of $1-4$, a density of $0.81-1.86 \mathrm{~km} / \mathrm{km}^{2}$ and a river stage that is at a young - mature stage.

The authors would like to thank the STTNAS/ITNY for funding the internal research as well as support the publication.

\section{References}

1. L. Zhang \& E. Guilbert, Int. J. of Geographical Inf. Sci., 27,12, 2319-2342 (2013)

2. L. Zhang \& E. Guilbert, Int. Archives of the Photogrammetry, Remote Sensing and Spatial Inf. Sci., XXXIX-B2, 29-34 (2012)

3. T. Listyani R.A., N. Sulaksana, B.Y.C.S.S.S. Alam, A. Sudradjat, A.D. Haryanto, Int. J. of GEOMATE, 14, 46, 177-184 (2018)

4. T. Listyani R.A., N. Sulaksana, B.Y.C.S.S.S. Alam, A. Sudradjat, Int. J. of GEOMATE, 17, 60, 83-89 (2019)

5. T. Listyani R.A., and S.N. Peni, IOP Conf. Ser.: Earth Environ. Sci., 448, 012038 (2020)

6. T. Listyani R.A., Proc. of ReTII -14 Seminar, 332-337 (2019)

7. G. Asadollahfardi, N. Heidarzadeh, A. Sekhavati, A. Rashtizadeh, A. Samadi, Desalination and Water Treatment, 192, 97-110 (2020)

8. D. Allen, T. Datry, K. Boersma, M. Bogan, A.J.Boulton, D. Bruno, M. Busch, K. Costigan, W.K.Dodds, K. Fritz, Wiley Interdisciplinary Reviews: Water (2020)

9. M. Allaby, A Dictionary of Ecology, $4^{\text {th }}$ ed., (2010)

10. D. Isnawan, T. Listyani R.A., and F. Noormansyah, KURVATEK, 2, 2, 11-23 (2017)

11. L. Zhang*, E. Guilbert, Int. Archives of the Photogrammetry, Remote Sensing and Spatial Inf. Sci., XL-2/W1(2013)

12. L. Zhang \& E. Guilbert, Int. J. Geo-Inf., 5, 230 (2016)

13. S.A. Drummond, G. Erkeling, Encyclopedia of Planetary Landforms (2014)

14. A. Chaput-Bardy, C. Fleurant, C. Lemaire, J. Secondi, Ecological Modelling, 220, 3589-3598 (2012)

15. T. Listyani R.A. and Ev. Budiadi, Indonesian J. on Geoscience, 5, 3, 265 -276 (2018) 
16. J. V. Pérez-Peña, A Azor, J. M. Azañón, E. A. Keller, Geomorphology, 119, 74-87 (2010)

17. S. Bahrami, D. Capolongo, M. R. Mofrad, Geomorphology, 355, 1-20 (2020)

18. W. Luo, B. Grudzinski, D. Pederson, Geomorphology, 125, 414-420 (2011)

19. M. Rubinato, A. Nichols, Y. Peng, J. Zhang, C. Lashford, Y. Cai, P. Lin, S. Tait, Water Science and Engineering, 12, 4, 274-283 (2019)

20. G. Zaimes, R. Emanuel, Stream Processes Part 1: Basics (2014) 